\title{
TEACHING WRITING BY USING PEER EXCHANGE TECHNIQUE
}

\author{
Vita Vendityaningtyas
}

\begin{abstract}
Writing is commonly considered as the most difficult skill to learn. It is due to the skills involved in writing, which are highly complex. A learner has to be aware of higher level skills of planning and organizing as well as the lower one of spelling, word choice, punctuation, and so on. Students also need interaction with others to gain more views or ideas.

Peer exchange is a technique which allows a teacher to ask students to read one another's papers and to write feedback notes. It will be useful to arrange students to help one another to improve their written work. This technique is believed to be able to accommodate the students' need of interaction and get feedback from others that finally will stimulate them to think more critically to make their own written work.

This technique itself works in such a way: (1) teacher asks the students to take the paper they have written and pass it to someone else; (2) students keep the papers face down, until teacher commands them to do so; (3) when the teacher commands them "Go ahead!" students are to look over the papers and to provide some written feedback: things they feel interested about the paper; suggestions for improvement; questions; or any other constructive idea; and (4) teacher reminds the students that the goal is to help the person do much better than he already did

Peer exchange is believed to be useful in writing activity for it is able to: (1) get all students look over others' work so they will know some works done better than theirs; (2) perform active learning highly; (3) provide lot of feedback to students very efficiently than teacher alone could provide.
\end{abstract}

Keywords: teaching writing, peer exchange, feedback spelling, word choice, punctuation, and so

\section{Introduction}

Writing is commonly considered as the most difficult skill to learn. According to Richards and Renandya (2002: 303), the difficulty lies not only in generating and organizing ideas but also in transforming these ideas into readable text. It is also due to the skills involved in writing, which are highly complex. A learner has to be aware of higher-level skills of planning and organizing as well as the lower one of on.

The problem is getting worse when the class condition also could not encourage the students to be more active. It was caused by its quite monotonous activity. The students just wrote and wrote meaning that they were not able to show and get feedback among others.

Therefore, peer exchange technique may be chosen in effort of improving the students' writing ability. This technique is believed to be able to accommodate the 
students' need of interaction and get feedback from others-without decreasing the main role of the teacher-that finally will stimulate them to think more critically to make their own written work.

\section{Theory of Writing}

\section{A. Definition of Writing}

Writing is a means of communicating ideas and information that makes it an essential part in foreign language learning. Byrne (1997, p. 1) proposes that writing is a sequence of sentences arranged in a particular order and linked together in certain ways. As a support to this statement, it is said that writing is the process of carving characters on a medium, with the purpose of forming words and other larger language constructs ("Writing - Definition," n.d.).

Meanwhile, Klein (1985 in Tan, 2009) suggests that writing is the ability to put pen and paper to express ideas through symbols. Richards and Renandya (2002, p. 303) add that writing can be the most difficult skill for L2 learners to master for it involves highly complex skills. Learners have to conquer the higher-level skills of planning and organizing as well as the lower ones: spelling, punctuation, word choice, etc.

From the definitions above, it can be concluded that writing is a means of communicating and expressing ideas in the form of arranged written sentences using a set of signs or symbols on a medium, which applies the importance of the organization, content, grammar, mechanics, and vocabulary.

\section{B. Skills in Writing}

Writing requires its learners to meet some skills. This will also show the learner's achievement and teacher's target fulfillment. Brown (2004, p. 221) classifies the writing skill into microskills and macroskills.

1. Microskills:

a. Produce graphemes and orthographic patterns of English

b. Produce writing at an efficient rate of speed to suit the purpose

c. Produce an acceptable core of words and use appropriate word order patterns

d. Use acceptable grammatical systems (e.g. tense, agreement, pluralization), patterns, and rules

e. Express a particular meaning in different grammatical forms

f. Use cohesive devices in written discourse

2. Macroskills

a. Use the rhetorical forms and conventions of written discourse 
b. Appropriately accomplish the communicative functions of written texts according to form and purpose

c. Convey links and connections between events, and communicate such relations as main idea, supporting idea, new information, given information, generalization, and exemplification

d. Distinguish between literal and implied meanings when writing

e. Correctly convey culturally specific references in the context of the written text

f. Develop and use a series of writing strategies, such as accurately assessing the audience's interpretation, using prewriting device, writing with fluency in the first drafts, using paraphrases and synonyms, asking for peer and instructor feedback, and using feedback for revising and editing.

\section{Theory of Peer Exchange Technique}

Peer exchange is a technique, which allows a teacher to ask students to read one another's papers and to write feedback notes. It will be useful to arrange students to help one another to improve their written work (Bangert-Downs, et al., 1991 in Harmin and Toth, 2006, p. 226).

As a note, this technique may appear in different name but similar in the concept, such as peer review, peer response, or peer feedback. As what has been stated by Gildersleeve (2009), as a common feature of composition courses, peer review can be a valuable teaching strategy in any course where writing is involved. It functions essentially the same way as writing workshops.

Then, it can be assumed that the exchange here is mainly aimed at giving feedback and editing a piece of written work. The editing is obtained by the students' feedback notes or commentary when they exchange their work.

There is also what is called as "Comment Form" from Victoria Chan (in Modern English Teacher in Harmer, 2004, p. 116) to help students in giving comments or feedback in this activity: 
Figure 3.1

Example of Comment Form

\section{COMMENT FORM}

- When reading your classmate's text, you could also tell them your responses to the following points:

a) My immediate reactions to this piece of writing are ...

b) I find the content ...

c) I like the part on ...

d) The part on ... could be further developed/elaborated

e) You tend to ...

f) I'm not sure about ...

g) The specific language errors that I have noticed are...

h) The best part of this writing is ...

- Also, give suggestions on areas that need to be improved

As a support to this concept, Harmer (2004, p. 111) suggests that teacher may also make a kind of first agreement with the students about the way of correcting or giving feedback. One of them is by using symbols. This is based on the consideration of minimizing the use of the red ink. It also will be useful to stimulate students to think more critically and curiously, about the mistakes they have made in their writing piece. Then, students may also use them in giving feedback notes or commentary to their friend's work. The following are the frequently used symbols in giving correction:
Table 3.2

Frequently Used Symbols in Correction

\begin{tabular}{|c|c|c|}
\hline SYMBOL & MEANING & $\begin{array}{l}\text { EXAMPLE } \\
\text { ERROR }\end{array}$ \\
\hline$S$ & A spelling error & $\begin{array}{l}\text { The conclution is } \\
\text { obvious. }\end{array}$ \\
\hline WO & $\begin{array}{l}\text { Mistake in word } \\
\text { order }\end{array}$ & $\begin{array}{l}\text { She very love the } \\
\text { boy much. }\end{array}$ \\
\hline $\bar{G}$ & Grammar mistake & $\begin{array}{l}\text { I am going to buy } \\
\text { some furnitures. }\end{array}$ \\
\hline $\mathrm{T}$ & Wrong verb tense & $\begin{array}{l}\text { I have seen him } \\
\text { yesterday. }\end{array}$ \\
\hline $\mathrm{C}$ & $\begin{array}{l}\text { Concord mistake } \\
\text { (e.g. subject-verb } \\
\text { agreement) }\end{array}$ & $\begin{array}{l}\text { The people is } \\
\text { angry. }\end{array}$ \\
\hline$\lambda$ & $\begin{array}{l}\text { Something has } \\
\text { been left out }\end{array}$ & $\begin{array}{l}\text { He told } \lambda \text { that he } \\
\text { loves chocolate. }\end{array}$ \\
\hline WW & Wrong word & $\begin{array}{l}\text { It is different with } \\
\text { what I thought. }\end{array}$ \\
\hline\{\} & $\begin{array}{l}\text { Something is not } \\
\text { necessary }\end{array}$ & $\begin{array}{l}\text { He was not }\{\text { too }\} \\
\text { strong enough. }\end{array}$ \\
\hline$P$ & $\begin{array}{l}\text { Punctuation } \\
\text { mistake }\end{array}$ & $\begin{array}{l}\text { Do you like } \\
\text { London. }\end{array}$ \\
\hline $\mathrm{F} / \mathrm{I}$ & $\begin{array}{l}\text { About formal or } \\
\text { informal }\end{array}$ & $\begin{array}{l}\text { Hi, Mr. Franklin. } \\
\text { Thank you for your } \\
\text { letter ... }\end{array}$ \\
\hline
\end{tabular}

\section{The Strengths}

Peer exchange is believed to be able to:

a. Get all students look over others' work so they will know some works done better than theirs that will improve each student's written work

b. Perform active learning highly

c. Provide lot of feedback to students very efficiently than teacher alone could provide (in Bangert-Downs, et al., 1991 in Harmin and Toth, 2006, p. 228).

Still there are some other similar benefits of this technique proposed by other experts. Harmer (2004, p. 12) argues that this technique may be useful in providing a welcome alternative to the teacher's feedback as well as proposing a fresh view in writing. Meanwhile, 
Gildersleeve (2009) suggests that this technique may offer several important learning benefits to students:

a. First, it makes students aware of the requirement of writing for an audience other than their instructor/teacher/lecturer.

b. Understanding how readers may respond to the student's own views or topic can give them valuable insight

c. Second, peer review forces students out of their comfort zones. Many students try to involve themselves in college courses by contributing as little as possible. But a peer review makes sharing their work compulsory

d. Third, it offers a fairly low-risk environment in which students can learn to express themselves and work in groups, skills they will find necessary in most professions.

e. Last, students learn how to give and receive feedback, thing that may be difficult for them.

It was also suggested by Keh (1990) that through feedback, the writers would learn to give the readers enough information, logic organization, good development of ideas, or appropriate wordchoice or tense.

\section{Weaknesses of Peer Exchange}

On the other hand, students may feel uncomfortable commenting on their friends' work. They also may make misperception in giving the feedback. Meanwhile, Harmer (2004, p. 117) also suggests that peer exchange/review is not a problem-free technique. First, students may underestimate their peer's comments especially those who rely much on their teacher's feedback. Second, not all students can work well together. The success of this technique will depend on who is the reviewer and whose work is being reviewed. These may be assumed as the weaknesses of this strategy.

\section{Technique Application}

1. The Procedure of Peer Exchange Peer exchange involves the following process (Bangert-Downs, et al., 1991 in Harmin and Toth, 2006, p. 227):

a. Teacher asks the students to take the paper they have written and pass it to someone else

b. Students keep the papers face down, until teacher commands them to do so

c. When the teacher commands them "Go ahead!" students look over the papers and provide some written feedback: things they feel interested about the paper; suggestions for improvement; questions; or any other constructive idea

d. Teacher reminds the students that the goal is to help the person do much better than he already did 
Then, in teaching and learning activity, the process can be as follow:

1. Pairing the students (those in better achievement are paired with those in lower achievement)

2. Exchanging their work with peer

3. Students give feedback to their peer's writing by using "Peer Exchange Sheet"

This activity can be extended by having some students present their comments in front of the class.

The example of students' commentary feedback sheet could be seen as follow:

Figure 2

Example of Peer Exchange Sheet

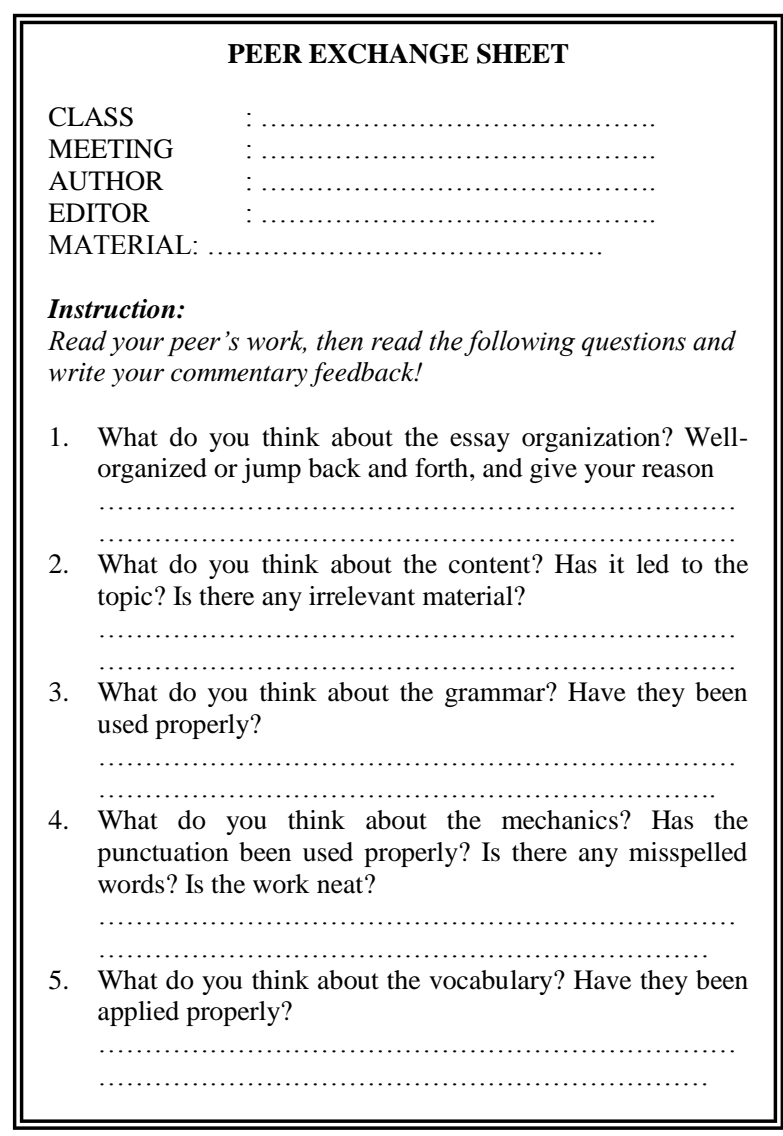

\section{Conclusion}

The implementation of peer exchange technique may be valuable into writing activity. This technique can get all students look over others' work so they will know some works done better than theirs that will improve each student's written work and perform active learning highly. That is why, it may be useful in providing a welcome alternative to the teacher's feedback as well as proposing a fresh view in writing.

Finally, teachers, students, or other learners are encouraged to apply this technique.Furthermore, they can explore the technique or make variations to get better understanding and achievement.

\section{References}

Richards, Jack C and Renandya, Willy A (Eds). (2002). Methodology in Language Teaching: An Anthology of Current Practice. New York: Cambridge University Press.

Byrne, Donn. (1997). Teaching Writing Skills (New Edition). London: Longman.

Writing - Definition. (n.d.). Retrieved from http://www.wordiq.com/ definition/Writing.

Tan, Hedda. (2009). What is Writing and Why is There a Need to Learn It? Retrieved from http://www.heddatan.com/adefinition-of-writing.html.

Brown, H Douglas. (2004). Language Assessment: Principles and 
Classroom Practices. New York:

Longman.

Bangert-Downs, RL, et al., (1991). The Instructional Effects of Feedback Test-like Events. Review of Educational Research, 61 (2). 213238 in Merrill Harmin and Melanie Toth. 2006. Inspiring Active Learning: A Complete Handbook for Today's Teachers. (Expanded $2^{\text {nd }}$ edition). (pp. 226-228).

Alexandria: Association for Supervision and Curriculum Development.

Gildersleeve, Greg. (2009). Peer Reviews as Teaching Strategy: Use Writing Workshops to Stimulate Student Writing. Retrieved from http:// academicwriting.suite101.com/artic le.cfm/peer_reviews_as_teaching_s trategy

Harmer, Jeremy. (2004). How to Teach Writing. Essex: Pearson Education Limited.

Keh, Claudia L. (1990). Feedback in the Writing Process: A Model and Methods for Implementation in ELT Journal volume 44/4 October 1990. Retrieved from http://203.72.145.166/elt/files/44-45.pdf. 
